\title{
PENETAPAN NILAI LIMIT HAK TANGGUNGAN DIBAWAH HARGA WAJAR OLEH KREDITOR ATAU PENJUAL
}

\author{
Oleh :
}

\author{
Mohamad Nasichin*, Ade Candra** \\ * Fakultas Hukum, Universitas Gresik \\ Email : muhammadnasichinsh@gmail.com \\ ** Fakultas Hukum, Universitas Gresik \\ Email : adycandra383@gmail.com
}

\begin{abstract}
In the determination of the limit value of the object of the Mortgage by the seller or creditors, it results in many losses for the debtor, the creditor on the pretext of paying off the creditors' receivables determines the value of the collateral object value below the fair value, even often the seller sets the limit value with the debtor's debt value. In the case of a creditor auctioning an object of mortgage on his own power through a public auction of object of mortgage, if the debtor is default, he should still consider that the object of mortgage is the property of the debtor. Because the debtor is the mortgage provider and the creditor should still prioritize the value of respect for the property of others. In this study, it is emphasized that in the implementation of the guarantee auction of Mortgage Rights through a Public Auction, KPKNL has not been able to provide the right and balanced solution between debtors and creditors. Because, in the Regulation of the Minister of Finance concerning Instructions for auction implementation, it does not define the determination of the lowest limit and the flow of determining the auction which is required to sell at market price first and does not provide a limit value below the liquidation value, besides that in the PMK it does not give authority to auction officers. KPKNL to impose sanctions on non-payment applicants if there is a price request by selling below a reasonable limit. So that the auction results are considered not fulfilling the principle of justice for the owner of the Object of the Mortgage.
\end{abstract}

Keywords: Mortgage Guarantee; Default Loan; Determination of Limit Value; Debtor Legal Protection

\begin{abstract}
Abstrak
Dalam penetapan nilai limit Objek Hak Tanggungan oleh penjual atau kreditor banyak mengakibatkan kerugian bagi debior, kreditor dengan dalih untuk melunasi piutang kreditor menetapkan nilai objek jaminan hak tanggungan dibawah nilai yang waja, bahkan sering terjadi penjual menetapkan nilai limit dengan nilai hutang debitor. Dalam halnya kreditor melakukan lelang objek hak tanggungan atas kekuasan sendiri melalui pelelangan umum objek hak tanggungan apabila debitor cedera janji seharusnya tetap mempertimbangkan bahwa objek hak tanggungan tersebut merupakan milik debitor. Karena debitor sebagai pemberi hak tanggungan dan seharusnya kreditor tetap mengedepankan nilai penghormatan kepada milik orang lain. Dalam penelitian ini menggaris bawahi bahwa dalam pelaksanaan lelang jaminan Hak Tanggungan melalui Pelelangan Umum yaitu KPKNL belum bisa memberikan solusi yang tepat dan
\end{abstract}


seimbang atara debitor dan kreditor. Karena, didalam Peraturan Menteri Keuangan Tentang Petunjuk Pelaksanaan lelang tidak mendefinisika mengenai penetapan batas terendah dan alur penentuan lelang yang di haruskan menjual dengan harga pasaar terlebih dahulu dan tidak memberikan nilai limit di bawah nilai likuidasi, selain itu di dalam PMK tidak memberikn kewenagan kepada petugas lelang KPKNL untuk memberikan sanksi kepada pemohon lelanag apabila adanya permaian harga dengan menjual dibawah limit yang wajar. Sehingga hasil lelang dianggap tidak memnuhi asas keadilan bagi pemilik Objek Hak Tanggungan.

Kata Kunci : Jaminan Hak Tanggungan; Kredit Bermasa Cedera Janji; Penetapan Nilai Limit; Perlindungn Hukum Debitor.

\section{A. PENDAHULUAN}

Perbankan atau bank merupkan lembaga yang dapat membantu dan menunjang dalam memajukan ekonomi dan taraf hidup masyarakat dalam mengembangkan usaha atau sebatas memenuhi kebutuhan. Dengan adanya lembaga perbankan tersebut maka masyarakat yang membutuhkan dana atau modal baik untuk perusahaan ataupun untuk pemenuhan kebutuhan ekonomi lainnya dapat mengajukan permohonan kredit atau pinjaman kepada pihak bank, yang mana yang dimaksudkan dengan bank “...adalah semua badan uasaha yang bertujuan untuk menyediakan jasajasanya jika terdapat permintaan atau penawaran akan kredit". ${ }^{1}$

Bank sebagai pemberi pinjaman tentunya akan meminta debitor untuk memberikan atau meneyediakan suatu jamianan sebagi agunan, perbankan sudah tentu menerapkan asas kehati-hatian dalam menyalurkan dana perkreditanya. Pihak perbankan akan lebih memilih memberikan pinjaman atau kredit kepada debitor yang mempunyai jaminan, walaupun prinsip dari suatu agunan

1 C.S.T.kansil dan Chistrine, Pokok Pokok Pengetahuan Hukum Dagang Indonesia, Edisi Kedua, Sinar Grafika,Jakarta, 2013. hal. 240. itu merupakan salah satu unsure saja.

...Pada prinsipnya agunan itu merupakan salah satu unsur saja dalam pemberian kredit guna memperkecil resiko dalam menyalurkan kredit, karena pada prinsip tersebut tidak selalu suatu penyaluran kredit harus adanya aguanan atau barang jaminan (collateral), sebab jenis usaha dan peluang bisnis yang di miliki debitur pada dasarnya sudah merupakan jaminan terhadap prospek usaha itu sendiri atau dengan kata lain, apabila unsur-unsur yang ada telah dapat meyakinkan kreditor atas kemampuan debitor maka jaminan cukup hanya berupa jamian pokok saja dan bank tidak wajib meminta jaminan tambahan. ${ }^{2}$

Dengan demikian yang paling dianggap aman sebagai objek jamian dari pihak debitor sebagai jaminan atas hutang atau kreditnya adalah hak atas tanah. Penggunaan jaminan hak atas tanah merupakan hal yang sangat penting dalam pemberian kredit karena tanah selain di anggap sangat aman dijadikan

\footnotetext{
${ }^{2}$ Habib adjie, Hak Tanggungan Sebagai Lembaga jaminan Atas Tanah, Edisi Revisi, Mandar maju, Bandung, 2018. hal. 2.
} 
sebagai jaminan atau agunan, tanah pada umumnya sangat mudah di jual. Tanah mempunyai nilai atau harga yang cenderung naik atau selalu meningkat, tidak mudah musnah atau hilanag dan mempunyai tanda bukti hak, serta dapat dibebani sebagai hak tanggungan.

Pada asasnya tidak ada kredit yang tidak mengandung jaminan, sesuai dengan Pasal 1131 Kitab Undang-Undang Hukum Perdata (selanjutnya disebut BW) "Segala kebendaan si berutang baik yang bergerak maupun yang baru akan ada di kemudian hari menjadi tanggungan untuk segala perikatan perseoranagn.

Tidak sedikit terjadinya gagal bayar atau cedera janji atau wanprestasi dari pihak debitor yang kemudian mendorong kreditor untuk melakukan lelang atas objek hak tanggungan debitor untuk menutupi piutang debitor. Pada saat inilah sering terjadi pelelangan yang tidak sesui harapan yaitu adanya pelelang dibawah limit harga yang wajar.

Berdasarkan uraian latar belakang di atas, serta agar permasalahan yang akan diteliti menjadi lebih jelas dan penulisan penelitian ini sesui dengan tujuan yang di inginkan, maka permasalahan pokok yang akan di teliti penulis adalah sebagi berikut:

1. Bagaimana kajian yuridis terhadap pelelangan jaminan objek hak tanggungan debitor yang cedera janji?

2. Apa upaya yang dapat dilakukan oleh debitor atas kerugian dengan dilakukanya pelelangan objek hak tanggungan yang di lelang di bawah harga limit yang wajar? Dalam menentukan tujuan yang hendak di capai dari penelitian ini, maka berdasarkan latar belakang permasalahan, perumusan masalah serta untuk mendapatkan ketentuan peraturan perundang-undanagn yang mengatur dari perumusan masalah di atas maka penulis mempunyai tujuan sebagai berikut:

1. Penelitian ini bertujuan untuk mengetahui bagaimana kajian yuridis terhadap pelelangan jaminan objek hak tanggungan debitor yang cedera janji.

2. Penelitian ini bertujuan untuk mengetahui apa upaya yang dapat dilakukan debitor atas kerugian dengan dilakuknnya pelelangan hak tanggungan di bawah harga limit yang wajar.

\section{B. METODE PENELITIAN}

Penelitian ini menggunakan jenis penelitian hukum normatif, untuk mendapatkan Informasi dan berbagai aspek mengenai isu yang sedang di teliti dan untuk mendaptkan jawabanya, maka pendekatan pendekatan yang di ambil dalam penelitian ini yaitu: Pendekatan Undang-Undang (statute approach), Pendekatan Konsep (statute approach), pendekatan kasus (case approaceh) yamg didukung dengan bahan bahan hukum primer yang relevan dengan isu hukum.

Jenis data yang digunakan dalam penelitian ini adalah data sekunder (secondary data), yaitu data yng di peroleh dari studi kepustakaan yang mencakup berbagai buku, dokumen resmi, peraturan perundang-undangan, 
hasil penelitian ilmiah yang berupa laporan serta bahan-bahan kepustakaan yang berkaitan dengan permasalahan yang diteliti. Yang bahan hukum tersebut memiliki keterkaitan yang sesuai dengan permasalahan yang di teliti. Bahan yang mengikat dalam peraturan perundang-undangan yang berkaitan dengan poko penelitian: Bahan hukum primer yang digunakan dalam penelitian ini, yaitu Undang-Undang Nomor 4 Tahun 1996 tentang Hak Tanggungan Atas Tanah Beserta Benda-Benda yang Berkaitan dengan Tanah, Undang-Undang Nomor 10 Tahun 1998 tentang Perubahan Atas Undang-Undang Nomor 7 Tahun 1992 tentang Perbankan, Undang -Undang Nomor 8 Tahun 1999 tentang Perlindungn Konsumen, Kitab Undang Undang Hukum Perdata, Peraturan Menteri Nomor 27 / PMK / 2016 Tentang Pelaksanaan Lelang dan peraturan perundangundangn lainya yang relevan dengan isu penelitian.

Bahan hukum sekunder yaitu bahan hukum yang memberikan penjelasan mengenai bahan hukum primer melalui hasil penelitian hukum, hasil karangan ilmiah dari kalangan hukum, dan artikel baik dari media cetak ataupun media massa yang berkaitan dengan pokok bahasan yaitu perlindungan hukum terhadap debitur ketika kreditur ketika terjadinya wanprestasi dalam suatu perjanjian dan kredit melelang objek hak tanggungan deditur di bawah limit haraga pasar. Bahan hukum tersier yaitu bahan yang memberikan petunjuk maupun penjelasan terhadap bahan hukum primer dan sekunder, yaitu kamus hukum, ensiklopedia, dan sebagainya.

\section{PEMBAHASAN}

Pelelangan Jaminan Objek Hak

Tanggungan Debitor yang Cedera Janji

Pemberian kredit oleh bank merupakan suatau fungsi utama yang di miliki oleh pihak perbankan. Mengingat pemberian kredit memiliki resiko yang sangat tinggi bagi perbankan, maka perbankan akan berupaya untuk meminimalkan segala risiko kredit dengan cara meminta debitur untuk memberikan jaminan atas kredit yang diberikannya.

Dalam prakteknya perbankan mengenai yang berkaitan dengan jaminan kredit biasanya sudah diatur oleh peraturan bank sendiri. Peraturan I tersebut yaitu diantaranya mengatur mengenai objek jaminan kredit yang dapat diterima bank, ataumengenai mekanisme penilaiannya dan bagaimna carauntuk pengikatannya.

Pada pasal 1131 BW menentukan suatu kewajiban bagi debitor untuk memberikan jaminan kepada kreditor atas segala utang yang diterimanya, tanpa adanya penetuan jaminan yang bersipat khusus maka segala harta kekayaan debitor baik yang telah ada maupun yang akan datang akan menjadi jaminan ketika orang tersebut membuat suatau perjanjian.

Didalam ketentuan Pasal 8 Undang- Undang Perbankan dan penjelasanya, maka arti jaminan pemberian kredit diberikan arti yang lain dengan agunan. Jaminan pemberian kredit diartikan sebagi 
keyakinan atas kemampuan dan kesangupan debitor untuk melunasi utangnya sesuai dengan yang diperjanjikan. Dengan kata lain bahwa undang-undang perbankan telah memberikan arti yuridis bagi jaminan pemberian kredit bukan sebagai agunan kredit, sedangkan agunan kredit hanya merupakan salah satu unsur dari jaminan pemberian kredit.

Berdasarkan peraturan perundang-undangan yang mengatur atau berkaitan dengan masing masing barang yang ditetapkan sebagai objek jaminan kredit akan dapat dinilai.

Tanah yang diajukan oleh calon peminjam (debitor) sebagai jaminan kredit terlebih dahulu harus dinilai berdasarkan ketentuan UUPA No. 5 tahun 1960. Tanah yang termasuk sebagi tanah yang sudah terdaftar sehingga mempunyai sertifikat adalah berupa Hak Milik, Hak Guna Bangunan, Hak Guna Usaha, dan Hak Pakai. Sementara itu untuk tanah yang belum terdaftar yang kemudian diajukan sebagi objek jaminan kredit dan akan dibebani hak tanggungan, maka perlu diteliti kemungkinan pendaftarannya dan dalam hal ini merujuk pula pada ketentuan PP.No.24 Tahun 1997.

Dalam dunia perbankan disaat adanya kerditor yang mengalami cedera janji maka sesuai dengan Peraturan bank Indonesia No.7/2/PBI/2015 tentang Penilaian Kualitas Aktiva Bank Umum. Ketentuan berikut selanjutnya untuk beberapa pasal telah di ubah dengan Peraturan Bank Indonesia No.8 / 2 / PBI /2006 Tentang Perubahan atas Peraturan Bank Indonesia No.7 /PBI
/ 2005 tentang Penilain Kulitas Aktiva Bank Umum. Menurut ketentuan pasal 12 ayat (3) Peraturan Bnak Indonesia No. 7/2/PBI/2005 tentang penilian kulitas aktiva bank umum, kualitas kredit dibagi menjadi lima kolektibilitas, yaitu lancar, dalam perhatian khusus, kurang lancar, diragukan, dan macet.

Berikut bebrapa mengenai masing-masing kulitas kredit tersebut:

1. Kredit lancar, yaitu jika memenuhi kriteria pembayaran angsuran pokok dan / atau bunga tepat, memiliki mutasi rekening yang aktif, ataubagian dari kredit yang di jaminkan dengan agunan tunai.

2. Kredit dalam perhatian khusus, yaitu jika memenuhi kriteria, terdapat tunggakan angsuran pokok dan/atau bunga yang belum melampaui 90 hari.

3. Kredit kurang lancar, yaitu jika memenuhi kriteria terdapat tunggakan angsuran pokok da/atau bunga yang telah melampaui 90 hari.

4. Kredit yang diragukan, yaitu apabila memenuhi kriteria Terdapat tunggakan angsuran poko dan/atau bunga yang telah melampaui 90 hari, atau sering terjadi cerukan yang bersifat permanen, atau terjadi wanprestasi lebih dari 180 hari, atau terjadi kapitalisasi bunga, atau dokumentasi hukum yang lemah baik untuk perjanjian kredit maupun pengikatan jaminan.

5. Kredit macet, yaitu apabila memenuhi kriteria Terdapat tunggakan angsuran pokok 
dan/atau bunga yang telah melampaui 270 hari,atau kerugian oprational ditutup dengan pinjaman baru, atau dari segi hukum maupun kondisi pasar, jaminan tidak dapat dicairakn pada nilai wajar.

Kredit katagori bermasalah merupkan resiko yang terkandung dalam setiap pemberian perkreditan oleh bank. Risiko tersebut berupa kedaan dimana kredit tidak dapat dikembalikan tepat pada waktunya. Kredit bermasalah tersebut bisa disebabkan oleh berbagai faktor, misalnya ada kesengajaan dari pihak pihak yang terlibat dalam proses kredit, kesalah prosedur pemberian kredit, atau disebabkan oleh faktor lain seperti faktor perekonomian yang tidak setabil.

Yang dimaksud penyelamatan kredit adalah suatu langkah penyelesaian kredit bermasalah melalalui perundingn kembali antara bank sebagi kreditur dan nasabah peminjam sebagai debitor, sedangkan penyelesian kredit adalah suatu langkah penyelesaian kredit bermasalah melalui lembaga hukum. Yang dimaksud dengan lembaga hukum adalah Panitia Urusan Piutang Negara (PUPN) dan Direktorat Jenderal Piutang dan Lelang Negara (DJPLN), melalui badan peradilan dan melalui arbitrase atau badan alternatif penyelesaian sengketa. ${ }^{3}$

Mengenai penyelamatan kredit bermasalah dapat dilakukan berdasarkan dengan Surat Edaran Bank Indonesia No. 26/4/BPPP tanggal 29 Mei 1993 yang pada

\footnotetext{
${ }^{3}$ Hermansyah, Op. Cit., hal.76-77
}

prinsipnya mengatur penyelamatan kredit bermasalah sebelum diselesaikan melalui lebaga hukum.

Dalam surat edaran tersebut yang di maksud dengan penyelesaian kredit bermasalah adalah:

1). Rescheduling (penjadwalan kembali), yaitu upaya hukun untuk melakukan perubahan terhadap beberapa syarat perjanjian kredit yang berkenaan dengan jadwal pembayaran kembali / jangka waktu kredit termasuk tenggang (grace period), perubahan jumlah angsuran.

2). Reconditioning (persyaratan kembali) yaitu melakukan perubahan atas sebagian atau seluruh persyaratan perjanjian, yang tidak terbatas hanya kepada perubahan jadwal angsuran, dan/atau jangka waktu kredit saja.

3). Restucturing (penataan kembali) yaitu upaya berupa melakukan perubahan syarat-syarat perjanjian kredit berupa pemberian tambahan kredit,atau melakukan konversi atas seluruh atau sebagian kredit menjadi perusahaan, yang dilakukan dengan atau tanpa rescheduling dan /atau reconditioning.

Dari berbagai ualsan di atas maka penulis menggaris bawahi mengenai lelang objek hak tanggungan dari debitur yang cedera janj, karena perjanjian perikatan yang dilakukan oleh para pihak tersebut diatas apabila terjadi wanprestasi atau gagal bayar kemudian akan dilakukan eksekusi yang salah satunya adalah 
mekanisme lelang barang jaminan. Maka, Pelaksanan lelang atas obejek hak tanggunagn debitor yang gagal bayar dapt di lakukan apa bila pihak kreditor sudah memenuhi dan menjalakan sebagaimna ketentuan peraturan Bank Indonesia. Sebagaimana didalam pasal 12 peraturan bank Indonesia No 7/2 / PBI /2005 yaitu,

Penetapan kualitas kredit dilakukan dengan melakukan analisis terhadap faktor penilaian sebagaimana dimaksud dalam Pasal 10 dengan mempertimbangkan komponenkomponen sebagaimana dimaksud dalam Pasal 11. Penetapan kualitas kredit sebagaimana dimaksud pada ayat (1) dilakukan dengan mempertimbangkan setiap faktor penilaian dan komponen, relevansi dari faktor penilaian dan komponen terhadap debitur yang bersangkutan, berdasarkan penilaian sebagaimana dimaksud pada ayat (1) dan ayat (2), kualitas kredit ditetapkan menjadi: lancar, dalam perhatian khusus, diragukan atau macet.

Selain ketentuan di atas dalam penyelesain kredit bermasalah atau cedera janji pihak kreditor pada Surat edaran bank indonesia No. 26/4/BPPP tanggal 29 Mei 1993 yang pada prinsipnya mengatur penyelamatan kredit bermasalah sebelum diselesaikan melalui lebagahukum.

Upaya Hukum Terhadap Kerugian Debitor Atas Pelelangan Objek Hak Tanggungan Yang Dilelang Dibawah Harga Limit yang Wajar

Dalam pemberian kredit, bank atau pihak pemberi selalu berharap agar debitur dapat memenuhi kewajibannya untuk melunasi semua

piutangnya dengan tepat pada waktunya terhadap kredit yang sudah diterimanya. Dalam praktek, tidak semua kredit yang sudah dikeluarkan oleh pihak bank dapat berjalan dan berakhir sesui keinginan. Tidak sedikit pula terjadinya kredit macet disebabkan oleh debitur tidak dapat melunasi kreditnya tepat pada waktunya sebagaimana yang telah disepakati dalam perjanjian kredit antara pihak debitur dan perusahaan perbankan. Hal-hal yang menyebabkan terjadinya kredit bermasalah misalnya karena debitur tidak mampu atau karena mengalami kemerosotan usaha atau bangkrut dan gagalnya usaha yang mengakibatkan berkurangnya pendapatan usaha debitur atau memang debitur segaja tidak mau membayar segala piutangnya karena karakter debitur tidak baik.

Maka berdasar kepada keadaan debitur yang demikian, pihak kreditur berupaya mengambil pelunasan piutang dengan penjualan asset jaminan debitur sehingga lahirlah Undang-Undang Hak Tanggungan (UUHT) yang dirancang memberikan kepastian hukum sebagai hak jaminan yang kuat, dengan ciri khas eksekusi mudah dan pasti.

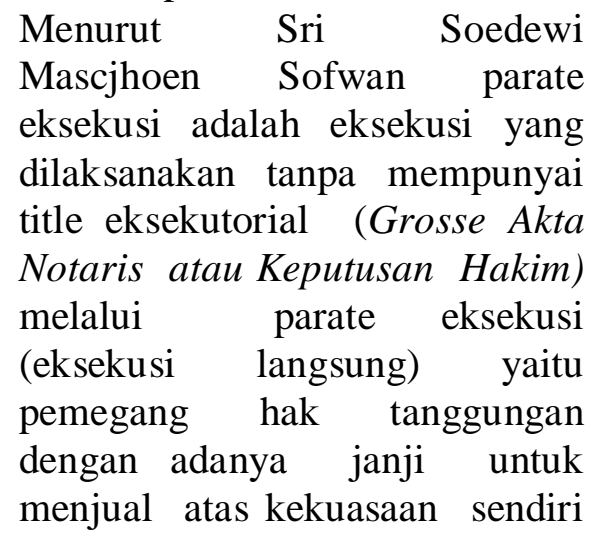


dapat melaksanakan haknya secara langsung tanpa melalui keputusan hakim atau grosse

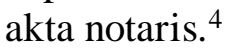

Salah satu fungsi dari jaminan hak tanggungan tersebut adalah adanya kepastian hukum bagi pihak bank selaku kreditor, apabila suatu hari debitor cedera janji atau tidak kunjung melunasi segala hutangnya sesuai dengan tanggal yang telah disepakati, maka jaminan hak tanggungan tersebut dapat dicairkan atau dilelang guna menutupi pelunasan utang debitor.

Atas jaminan hak tanggungan tersebut kekuasan kreditor hanya sebatas memiki hak atas utang yang belum terbayar oleh debitur baik utang yang disebutkan dalam perjanjian atau utang yang timbul setelah perjanjian pinjam meminjam dibuat, apabila setelah utang kreditor lunas dan masih ada sisa dari hasil penjualan jaminan hak tanggungan tersebut maka harus dikembalikan kepada pihak debitor..

Ketentuan dalam Pasal 20 ayat (1) a jo Psal 6 UUHT, yaitu: Apabila debitor cidera janji, pemegang hak tanggungan pertama mempunyai hak untuk menjual obyek hak tanggungan atas kekuasaan sendiri melalui perlelangan umum serta mengambil pelunasan piutangnya dari hasil penjualan tersebut, prosedur eksekusi parate yang dimaksud dalam Pasal 20 (1) a jo. Pasal 6 UUHT tersebut mensyaratkan adanya janji bahwa pemegang hak tanggungan pertama mempunyai

\footnotetext{
${ }^{4}$ Lanang Putra Perbawa, Penyelesaian Kredit Macet Dalam Perbankan, Tesis, Fakultas Hukum Universitas Maheswari, Denpasar. hal. 62.
}

hak untuk menjual atas kekuasan sendiri objek hak tanggungan apbila debitor cedera janji, sebagimana diatur dalam Pasal 11 ayat (2) e UUHT.

Selain itu, "Sertifikat hak tanggungan mempunyai fungsi sebagai grosse acte hyoptheek serta mempunyai kekuatan eksekutorial"5 sebagaimana dimaksud dalam Pasal 14 Undang-Undang Nomor 4 Tahun 1996 tentang Hak Tanggungan atas Tanah Beserta Benda-Benda yang berkaitan dengan tanah yang memuat irah-irah dengan kata-kata "DEMI

KEADILAN BERDASARKAN KETUHANAN YANG MAHA ESA" untuk memberikan kekuatan eksekutorial yang sama dengan halnya putusan pengadilan yang sudah mempunyai kekuatan hukum yang tetap.

Namun didalam kehidupan masyarakat yang dinamis ini diperlukan adanya penataan ulang mengenai peraturan lelang yang yang lebih khusus lagi terutama dalam penetapan harga limit oleh penjual. Sehinggga dapat digunakan sebagai sarana menjual barang dengan harga yang sesuai.

Pasal 20 UUHT mengatur dua sistem pelaksanaan pemenuhan pelunasan utang yang diikat dalam perjanjian hak tanggungan, yaitu Eksekusi objek Jaminan hak tanggungan. Ketentuan ini merupakan prinsip pokok yang diatur Pada pasal 20 jo. Pasal 6

5 Rizki El Fasti, Penentuan Harga Objek Lelang dalam Eksekusi Hak Tanggungan dilihat dari Perlindungan Kepentingan Debitor (Studi Putusan Pengadilan Negri Nomor 147 / PDT.G / 2013. PN.BDG \& NO 75/PDT.G/2011/PNYK), Tesis, Fakultas Hukum Universitas Sriwijaya, 2018, hal.3. 
UUHT.

1). Melalui parate eksekusi berdasarkan Pasal 224 HIR dan Pasal 6 UU Nomor 4 Tahun 1996 tentang Hak Tanggungan meminta fiat eksekusi kepada ketua PN.

2). Melalui penjualan lelang atas kekuasaan sendiri berdasarkan penjelasan Pasal 6, apabila dalam APHT, pemberi hak tanggungan berjanji bahwa pemegang hak tanggungan berhak menjual objek hak tanggungan dengan kekuasaan sendiri, maka penjualan lelang dapat dilakukan tanpa campur tangan pengadilan, pemegang tanggungan dapat langsung meminta pelaksanaan penjualan kepada kantor lelang / pejabat lelang.

Dalam hal adanya pelaksanaan penjualan yang dilakukan oleh pejabat lelang dapat dilakukan oleh balai lelang sebagaimana Keputusan Menteri Keuangan 40 / PMK.07 / 2006 tentang Balai Lelang. Namun demikian, sesuai lelangnya harus dilaksanakan dihadapan pejabat lelang dari Kantor Lelang Negara (KLN).

Dengan adanya kemudahan bagi kreditor untuk mengeksekusi objek hak tanggungan debitur yang cedera janji dengan cara lealng eksekusi, cara penjualan objek hak tanggungan dengan lelang ini ada kalanya tidak berfungsi dengan baik dan penjualan secara lelang masih menghadapi bebrapa kendala dan masalah yang bervariasi. Contohnya: adanya objek hak tanggungan yang dianggap telah dilelang dibawah nilai limit yang wajar dan tidak sesuai bagi debitur.

Di dalam proses lelang yang menggunakan harga limit, Pejabat Lelang berwenang mensahkan penawar tertinggi sebagai pembeli apabila penawaran yang diajukan telah mencapai atau melampaui harga limit yang ditentukan. Nilai limit pada lelang ini ditentukan oleh penjual, sebagaimana ketentuan Pasal 44 PMK No 27 / PMK.06 / 2016, baik pemilik barang maupun pemohon lelang, yakni orang / badan / pihak pihak / instansi yang berwenang yang oleh peraturan perundang-undangan dikuasakan untuk itu.

Nilai limit pada prinsipnya ditentukan berdasarkan permintaan penjual berdasarkan hasil penilaian terhadap barang yang akan dilelang tersebut, tetapi untuk lelang barang dengan harga jual diatas Rp. 1.000.000.000,- (satu milyar rupiah) penilaian atas barang yang dilelang harus dilakukan oleh penilai independent (independent appraisal) sebagaimana ketentuan yang tertuang dalam pasal 45 PMK No 27/2016, pasal 21 Vendu Reglement Staatsblad tahun 1908 nomor 189 juga merupakan salah satu persyaratan penjual.

Tujuan menentukan nilai limit sebagai patokan nilai minimal pada penjualan lelang bermaksud untuk menetapkan batas harga terendah yang dapat disetujui dan dibenarkan penjual. Penawar peserta lelang yang berada dibawah nilai limit haruslah ditolak. Oleh karena itu, berdasarkan nilai limit yang ditentukan sehingga lelang 
yang belum terlaksana sesuai dengan nilai limit yang disyaratkan. Akibatnya, lelang ditunda atau dibatalkan apabila penjual menghendakinya. ${ }^{6}$

Nilai limit tidak bersifat rahasia dan dapat dicantumkan dalam pengumuman, tetapi bisa saja apabila dilakukan sebaliknya, sesuai dengan keinginan penjual. Bila tidak rahasia, nilai limit diumumkan dalam pengumuman, sedangkan bila rahasia, nilai limit diberikan kepada Pejabat Lelang sebelum pelaksanaan lelang. Pasal 37 ayat (2) PMK tahun 2016 mengatakan bahwa, untuk lelang eksekusi, lelang non eksekusi wajib dan lelang non eksekusi sukarela atas barang tidak bergerak nilai limit wajib bersifat terbuka, yaitu dengan diumumkan jumlah harga limitnya, dengan tujuan untuk menghindari masalah di kemudian hari.

Dari bebrapa uraian diatas mengenai bebrapa mekanisme penetapan limit harga lelang jamiana hak tanggungan yaang merugikan pihak debitor contohnya:

Kepala desa (Kades) Jetis Edi Sasmito di Dusun Wonoayu, Desa / Kecamatan Jetis, Kabupaten Mojokerto. Gara-gara tidak bisa melunasi sisa utang di Bank Danamon, rumah yang dinilai seharga Rp 700 juta itu dilelang hanya seharga $\mathrm{Rp} 50$ juta. Juru Sita PN Mojokerto Muhammad Anwar mengatakan,

6 Rizki El Fasti, Penentuan Harga Objek Lelang dalam Eksekusi Hak Tanggungan Dilihat dari Perlindungan Kepentingan Debitor ( Studi Putusan Pengadilan Negri Nomor 147 / PDT.G / 2013.PN. BDG \& No 75/PDT.G /2011 ( $P N Y K)$, Tesis, Fakultas Hukum Universitas Sriwijaya, 2018. Hal 9-10. tanah seluas 402 meter persegi beserta bangunan ini sebelumnya milik Edi yang pada sertifikat hak milik atas nama Hartini. Sekitar tahun 2009 silam, Edi meminjam uang Rp 55 juta dari Bank Danamon dengan jaminan sertifikat rumah tersebut. Namun Edi tak mampu melunasi pinjamannya tersebut. Eks Kades Jetis itu hanya mengangsur sebanyak tujuh kali, sekitar Rp.21 juta."Tanah tersebut sudah dilelang. Lelang dimenangkan Rismawati warga Jalan Dukuh Kupang Timur, Surabaya senilai Rp 50 juta. Jadi sertifikat hak milik sudah atas nama Rismawati," terangnya. Sebagai pemenang lelang, lanjut Anwar, Rismawati pun mengajukan permohonan eksekusi ke PN Mojokerto. Pihak pengadilan mengabulkan permohonan Rismawati yang tertuang dalam Surat Penetapan Eksekusi No: 15/ Eks.HT / 2013 / PN.Mkt tertanggal 7 Maret 2016."Jadi eksekusi ini sudah berdasarkan kekuatan hukum tetap PN Mojokerto," pungkasnya. ${ }^{7}$

Dari contoh kasus diatas pihak pemilik barang jaminan (debitor) tentunya sangat merasa dirugikan, karena penetapan nilai limit jaminan yang dileleng sangat jauh dari harga pasar. Hal ini sangat merugikan debitor dan tentunya sangat tidak mungkin apabila setelah beberapa tahun kemudian harga dari objek

${ }^{7}$ https://news.detik.com/berita-jawatimur/d-3202733/utang-rp-55-juta-rumahmewah-eks-kades-dilelang-danamon-rp-50-juta, Diunggah Selasa, 03 Mei 2016 14:50 WIB, Diakses pada 12 juni 2020, Pukul. 15:55 
jaminan tersebut turun sangat drastis, kecuali jika tanah tersebut merupakan tanah sengketa, atau bangunan yang tidak terawat atau hal-hal lain yang mempengaruhi penurunan harga tanah dan bangunan.

Dengan demikian maka perlindungan hukum bagi debitor selaku konsumen di bidang perbankan menjadi penting, karena kedudukan antara para pihak seringkali tidak seimbang. Berdasarkan Peraturan Menteri Keuangan Nomor 27 / PMK.06 / 2016 telah memberikan kewenangan kepada KPKNL dalam melaksanakan yang sangat luas termasuk diantaranya lelang eksekusi.

Dalam pelaksanaan lelang khususnya lelang eksekusi, potensi gugatan sangat tinggi. Total gugatan yang masuk ke DJKN / KPKNL (berdasarkan Buletin Media Kekayaan Negara Edisi No.14 Tahun IV / 2013) adalah 2.458 dan 1.500 lebih adalah gugatan dari lelang eksekusi Pasal 6 hak tanggungan. Gugatan / Bantahan itu tersendiri diajukan sebelum pelaksanaan lelang dan pascalelang. Gugatan sebelum pelaksanaan lelang dimaksudkan oleh penggugat untuk menunda pelaksanaan lelang. Dan gugatan / bantahan pasca lelang sangat beragam motif yang melatarbelakanginya. ${ }^{8}$

\footnotetext{
8 Abdul Khalim, Buletin Direktorat jendral kekayaan Negara Kementerian Keuangan, https: // www.djkn.kemenkeu.go.id/artikel/baca $/ 5097$ Perbuatan -Melawan -Hukum-dalam-GugatanPelaksanaan - Lelang -di-KPKNL.html, di Unggah Senin, 14 April 2014, Pukul 07:52:55, diakses pada tanggal 22 Juni 2020, Pukul 15:54
}

Dengan adanya hubungan sebab akibat atas perbuatan kreditor yang menetapkan nilai limit dibawah harga yang wajar, maka akan menimbulkan kerugian bagi pihak debitor.

Dalam hal gugatan perbuatan melawan hukum yang pada pokok perkaranya mengenai penetapan nilai limit dibawah harga wajar, pihak KPKNL hanya bertanggung jawab mengenai prosedur yang berlaku yang dilaksanakan pada saat pelaksanaa lelang dilakukan bukan bertanggung jawab pada penetapan nilai limit dibawah harga wajar tersebut, karena pihak KPKNL tidak bertanggung jawab dalam penetapan nilai limit, pemohon lelanglah yang bertanggung jawab secara penuh terhadap penetapan nilai limit obyek hak tanggungan tersebut.

Berdasarkan analisa kasus diatas memperlihatkan bahwa sebuah perbuatan melawan hukum dalam proses pelaksanaan penetapan nilai limit dapat dengan jelas menjadi dasar pertimbangan untuk permohonan membatalkan hasil lelang karena tidak memnuhi ketentuan perjanjian yang disebutkan dalam Pasal 1320 jo 1335 BW. Dalam Pasal 1335 BW dijelaskan bahwa suatu perjanjian yang dibuat tanpa adanya sebab atau dibuat karena suatu sebab yang palsu atau terlarang adalah batal demi hukum. Yang mana didalam sebuah perjanjian tersebut harus dipenuhinya suatu syarat subyektif dan obyektif. Tindakan-tindakan merugikan yang sedari awal dilakukan oleh penjual dalam penetapan nilai limit lelang eksekusi dengan menetapkan nilai limit rendah agar proses penjualan 
obyek lelang dapat dengan mudah, dapat merugikan pihak lain dalam hal ini pemilik barang jaminan dan hanya menguntungkan penjual saja. Sehingga sebab dari perjanjian ini menjadi tidak halal, karena jauh dari kewajaran dimana dapat merugikan pihak tertentu. Oleh sebab itu dengan tidak terpenuhinya syarat obyektif tersebut diatas maka perbuatan melawan hukum dalam proses pelaksanaan penetapan nilai limit ini dapat dijadikan dasar untuk membatalkan lelang karena batal demi hukum.

\section{KESIMPULAN}

1). Didalam melakukn eksekusi atas hak tanggungan debitor yang cedera janji dengan lelang, maka kreditur harus berpegang pada Pasal 12 ayat (3) Peraturan Bank Indonesia tentang kualitas kredit dan Surat Edaran Bank Indonesia No 26/4/BPPP yang prinsipnya mengatur penyelamatan kredit bermasalah sebelum diselesaikan melalui lembaga hukum atau lembaga lelang dan senatiasa selalu menjaga hak-hak dasar debitor sebagai konsumen sebagimana dalam pasal 4 UUPK.

2). Tindakan - tindakan dalam penetapan nilai limit rendah oleh penjual atau kreditor pada lelang eksekusi dapat dipergunakan sebagai dasar pertimbangan menentukan adanya suatu perbuatan melawan hukum dalampengajuan proses pembatalan lelang di pengadilan dengan pertimbangan bahwa adanya perbuatan yang telah di lakukan oleh kreditor sebagai pemohon lelanag yang melanggar peraturan perundang undangan dan menyebabkan kerugian. Kesalahan dan hal tersebut merupakan kesengaja dilakukan penjual dan sebabnya menjadi tidak halal dan bertentangan dengan kewajaran. Hal demikian tersebut harus dipertanggung jawabkan sepenuhnya oleh penjual atau kreditor sebagimna Pasal 17 ayat 2 PMK No.27 / PMK.06 /2 016.

\section{E. DAFTAR PUSTAKA \\ Buku- buku}

Adjie Habib, Hak tanggungan Sebagai lembaga Jaminan Atas Tanah, Edisi Revisi,Mandar Maju, Bandung, 2018.

Bahsan. M, Hukum Jaminan dan Jaminan Kredit Perbankan Indonesia, Raja Grafindo Persada, Jakarta, 2015.

Harsono Boedi, Hukum Agraria Indonesia, Jilid 1 Hukum Tanah Nasional, Djambatan, Jakarta, 2008.

Hermansyah, Hukum Perbankan Indonesia, Edisi Kedua, Prenandamedia, jakarta,2005.

Kansil. C.S.T, S.T.Cristin, Poko Pokok Pengetahuan Hukum Dagang Indonesia, Edisi Kedua, Sinar Garafika, Jakarta, 2002.

\section{Pengantar}

Ilmu Hukum Indonesia, Rineka Cipta, jakarta, 2002.

Putra Perbawa I Ketut Sukowati, 
Penyelesaian kredit macet dalam Perbankan

Marjuki Peter Mahmud, Penelitian Hukum, Edisi Revisi, Prenandamedia Group, Jakarta, 2012.

Rustam Riky, Hukum Jaminan, UII Pers, Yogyakarta, 2017.

Soenandar Taryana, Dajamil, Badruljaman, Kompilasi Hukum Perikatan, Cetakan Kedua, Citra Aditya Bakti, Bandung, 2016.

Subekti, HukumPerikatan, Cetakan Keenam, Intermasa, Jakarta, 1990.

Setiawan I Ketut Okta, Hukum Pendaftaran Tanah dan Hak Tanggungan, Sinar Grafika, Jakarta, 2019.

Shierta Hery, Prakteh Hukum Jaminan Kebendaan, Citra Aditya Bakti, Bandung, 2016.

Usanti Trisandini Prasastinah, Bakarbessy Leonora, Buku Referensi Hukum Perbankan Hukum Jaminan, Surabya, 2014.

\section{Tesis-Tesis}

Fatoni Mohamad Fuad, Wewenang Tim Penilai (Appraisal) dalam Menentukan Nilai Limit Lelang, Program Magister Ilmu Hukum, Fakultas Hukum Universitas Islam Malang, Malang.

El fasti Ahamad Rizki, Penentuan Harga Objek Lelang dalam Eksekusi Hak Tanggungan dilihat dari perlindungan Kepentingan ( Studi Pustaka Pengadilan Negri Nomor 147/PDT.G/2013.PN.BDG \&Nomor
73/PDT.G/2011/PNYK),

Program Magister

Kenotariatan, Fakultas

Hukum Universitas

Sriwijaya, 2018.

Rianto Ria desmawati, Djatmika Prija, Hamidah Siti, Kajian Yuridis Pembatalan Lelang Eksekusi Karena Nilai Limit Rendah, Program Magister kenotariatan, Fakultas Hukum Universitar Brawijaya, Malang.

\section{Jurnal Hukum}

Sulastri Lusia, Kontruksi Perlindungan Hukum Debitur dalam Penyelesaian Kredit Bermasalah dengan Pelaksanaan lelang Jaminan Hak Tanggungan, Voleme II No. 1 Jurnal Pembaharuan Hukum, 1 januari-April 2015.

\section{Skripsi- Skripsi}

Chairany Melfi Futeri, Penerapan Prinsip Keadilan Terhadap Pelaksanaan lelang JaminaN Hak Tanggungan Dibawah Harga Wajar, Program Ilmu Hukum, Fakultas Hukum Universitas Isalam Indonesia, Yogyakarta, 2018.

\footnotetext{
Media Daring

Enggran Eko Budianto - detikNews di Unggah Selasa, 03 Mei $2016 \quad 14: 50 \quad$ WIB, https://news.detik.com/berita -jawa-timur/d3202733/utang-rp-55-jutarumah-mewah-eks-kadesdilelang-danamon-rp-50juta,
} 
Abdul Khalim-Artikel DJKN di Unggah Senin, 14 April 2014 Pukul 07:52:55, https://www.djkn.kemenkeu. go.id/artikel/baca/5097/Perb uatan-Melawan-Hukum-

dalam-Gugatan-

Pelaksanaan-Lelang-diKPKNL.html

\section{Peraturan Perundang Undangan}

KUHPerdata

Undang-Undang Nomor 4 tahun 1996 Tentang Hak Tanggungan Atas Tanah Beserta Benda-Benda Yang berakitan Dengan Tanah.

Undang-Undang Nomor 5 Tahuhn 1960 Tentang Peraturan Dasar Pokok-Pokok Agraria.

Undang-Undang Nomor 8 Tahun 1999 Tentang Perlindungan Konsumen.

Undang-Undang Nomor 10 Tahun 1998 Tentang Perubahan Atas Undang-Undang Nomor 7 Tahun 1992 Tentang Perbankan.

Undang- Undang Nomor.17 Tahun 1997 yang telah di ubah deng Undang-Undang Nomor 19 tahun 2000 Tentang Penagihan Pajak dengn Surat paksa.

Peraturan Menteri Keuangan Repoblik Indonesia Nomor 27/OMK.06/2016 Tentang Petunjuk Pelaksa Lelang.

Peraturan Menteri Keuangan Repoblik Indonesia Nomor.101/PMK.01/2014

Surat Edaran Bank Indonesia Nomor 26/4/BPPP tanggal 29 mei 1993 